\title{
Return to Sport, integrating the process from conventional rehabilitation up to reconditioning: a narrative review
}

\author{
Pavel Loeza-Magaña', Héctor R. Quezada-González², Pedro I. Arias-Vázquez³ \\ 'Centro Médico Nacional 20 de Noviembre, ISSSTE, Cd. de México. ${ }^{2}$ Clinica SportHabilia, Cd. de México. ${ }^{3}$ Universidad Juárez Autónoma de Tabasco, Tabasco, México.
}

doi: $10.18176 /$ archmeddeporte.00049

Received: $30 / 05 / 2020$

Accepted: 20/04/2021

Key words: Injury. Sport. Rehabilitation. Return to play.

\section{Summary}

Introduction: The process of return to sport after injury, has traditionally been approached in 2 separate stages; first the athlete is treated the medical service through conventional rehabilitation processes and is then referred to the sports team (coach and / or physical trainer) who complete the return to the sport activity. This approach may lack communication and coordination between both teams and may be insufficient for the demands of the current sports environment, causing longer processes of return to sport and greater risk of re-injury. The objective of this manuscript is to document the current models of return to sport, its stages, objectives and contents.

Material and method: A comprehensive review of publications was carried out, including observational studies, clinical trials, reviews, consensus, systematic reviews and meta-analysis, related to treatment, rehabilitation, readaptation and return to sport. Results: The description of a model of return to sports of gradual progression that includes 3 stages was found: return to participation, readaptation to sport and return to maximum sports performance. The stage of return to participation aims to eliminate the symptoms and regain the functionality of the athlete in their non-sports activities, through conventional rehabilitation processes. The stage of readaptation to sport aims to achieve asymptomatic performance of training and competition activities, through the rehabilitation of deficiencies caused by the injury and the maintenance and / or development of motor skills with modified training. The stage of return to maximum sports performance includes specific sports training to reach the level of performance prior to the injury.

Conclusions: This model could be associated with greater success in returning to sports activity and lower risk of recurrence of the injury.

\section{Retorno al deporte, integrando el proceso desde la rehabilitación convencional a la readaptación deportiva: revisión narrativa}

\section{Resumen}

Introducción: El proceso de retorno al deporte posterior a una lesión, ha sido abordado tradicionalmente en 2 etapas separadas: primero el atleta es tratado por el servicio médico mediante procesos de rehabilitación convencional y posteriormente es referido al equipo deportivo (entrenador y/o preparador físico) quienes completan el regreso a la actividad deportiva. Este abordaje puede carecer de comunicación y coordinación entre ambos equipos y tal vez es insuficiente para las demandas del entorno deportivo actual, originando procesos más largos de retorno al deporte y mayor riesgo de re-lesión. El objetivo de este manuscrito es documentar los modelos actuales de retorno al deporte, sus etapas, objetivos y contenidos.

Material y método: Se realizó una revisión exhaustiva de publicaciones que incluyó estudios observacionales, ensayos clínicos, revisiones, consensos, revisiones sistemáticas y meta análisis, relacionadas con el tratamiento, rehabilitación, readaptación y retorno a la actividad deportiva.

Resultados: Se encontró la descripción de un modelo de retorno a la actividad deportiva de progresión gradual que incluye 3 etapas: retorno a la participación, readaptación al deporte y retorno al máximo de rendimiento deportivo. La etapa de retorno a la participación tiene como objetivo eliminar la sintomatología y recobrar la funcionalidad del atleta en sus actividades no deportivas, mediante procesos de rehabilitación convencional. La etapa de readaptación al deporte tiene el objetivo de alcanzar la realización asintomática de las actividades de entrenamiento y competición, mediante la rehabilitación de las deficiencias originadas por la lesión y el mantenimiento y/o desarrollo de las capacidades motoras con entrenamiento modificado. La etapa de retorno al máximo rendimiento deportivo incluye el entrenamiento deportivo específico para alcanzar el nivel de rendimiento previo a la lesión.

Palabras clave: Lesión. Deporte. Rehabilitación. Retorno al juego.
Conclusiones: Este modelo, podría estar asociado a mayor éxito en el retorno a la actividad deportiva y menor riesgo de presentar reincidencia de la lesión. 


\section{Introduction}

A sports injury is defined as any physical or medical condition that may occur during participation in a sport or training activity and that results in an inability to participate in competitive or training activities and requires medical diagnosis and treatment ${ }^{1,2}$.

The process to return to sporting activity following an injury is known as Return to Sport (RTS) or Return to Play (RTP)3. This is a complex process that must take account of the biological-structural characteristics of the injury (type of injured tissue, extent of the injury, duration of the injury, signs and symptoms and characteristics of the injury reported in imaging studies), history of previous injuries and the athlete's state of health, functional losses generated by the injury (limitation of mobility, muscle weakness and imbalance, strength alterations, loss of balance, alterations in physical-functional tests), the factors relating to the sport in question (level of participation prior to the injury, competitive category or level, type of sport, position or test in the sport, stage of the season) and related personal, psychosocial and environmental factors (gender, age, race, non-sporting activities, job, psychological characteristics, family and/or social factors, external pressures, conflicts of interest, etc. $)^{3-5}$.

The RTP processes have traditionally been conducted in 2 separate stages: firstly, through medical treatment based on the conventional rehabilitation processes to subsequently be referred to the sports team (trainer and/or fitness coach) who complete the Return to Performance process $^{6}$ (Figure 1). However, this approach involved little communication between both teams and, on many occasions, proved to be insufficient for the demands of the current sports environment, given that it involved longer RTP processes with a high risk of re-injury and inability to return to the pre-injury level of performance ${ }^{6}$.

Therefore, this review aims to document the models currently proposed to conduct the RTP processes, to indicate the stages into

\section{Figure 1. Former RTP model.}

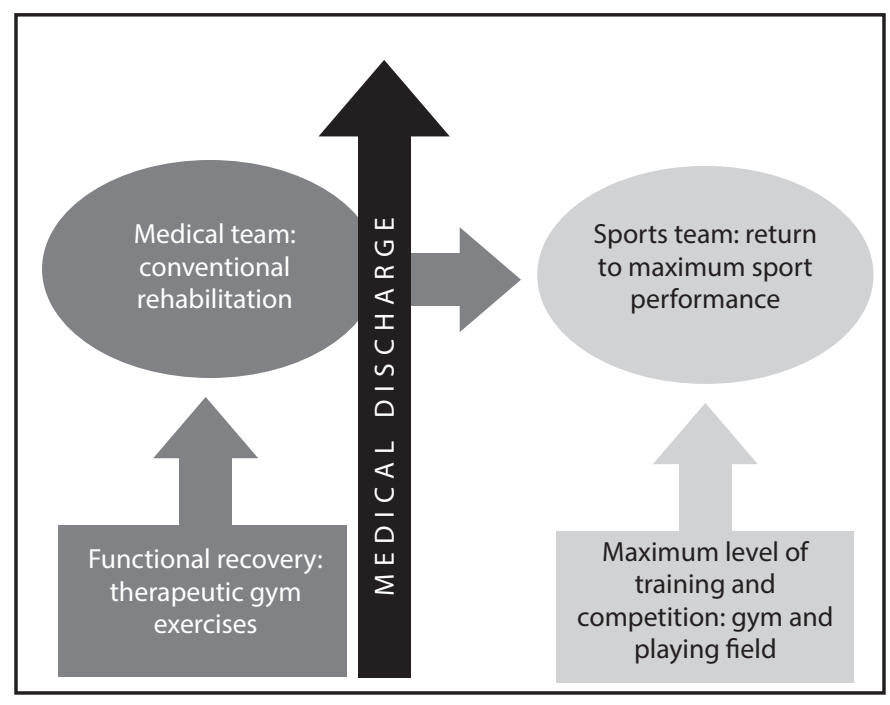

which this process is divided and to describe the goals and contents of each one.

\section{Material and method}

An exhaustive review of the literature published up to 30 March 2021 was conducted using the databases of PubMed, PeDro, Dialnet, and Google Scholar. This comprised observational studies, clinical trials, reviews of the literature, consensus statements, systematic reviews and meta-analyses that included information on strategies and interventions that are currently used in the treatment, rehabilitation and reconditioning to return to sport following injury, published in English or Spanish. The search strategy of the articles included was divided into 2 stages. In the first stage, documents were retrieved using the following search terms: "return to play" or "sports rehabilitation" or "sports reconditioning" and "sport injury" in order to identify those articles documenting the RTP process and defining the stages involved. Secondly, a direct search was made on the topics mentioned in the previously identified articles, including the analysis of the bibliography referenced in the same, for the purpose of supporting the information on the goals and contents of each of the RTP stages.

\section{Results}

\section{RTP integrated models}

The needs and demands of today's sport environment make it necessary to have more efficient and effective RTP protocols. Buckthorpe et al. ${ }^{6}$ highlight the need to include a "transition stage" to form a bridge between conventional clinical rehabilitation and sports training and that must take a multi-disciplinary approach, emphasising the involvement of the medical team with specialist training. Ardern et al. ${ }^{4}$ proposed an RTP model that contemplates 3 stages that form a therapeutic continuum: Return to Participation, Return to Sport and Return to Performance. The Return to Sport stage has also been termed On-field Rehabilitation ${ }^{6}$ or Sports Reconditioning ${ }^{7}$. Figure 2 is a schematic of the current RTP model.

\section{Return to Participation stage}

Within the RTP model proposed by Ardern et al. ${ }^{4}$, the first stage is the Return to Participation. This stage is normally coordinated by the medical team and is directed at establishing a diagnosis and prognosis of the injury and starting the treatment and rehabilitationof the injury as soon as possible.

During this stage, the injured athlete participates in the conventional clinical rehabilitation process and also takes part in modified or restricted training sessions. The contents are focussed on recovering the functionality level in order to perform the activities of daily living with no symptoms and to maintain one's physical condition as far as possible with no risk of greater injury ${ }^{4,6}$. 
Figure 2. Current RTP model.

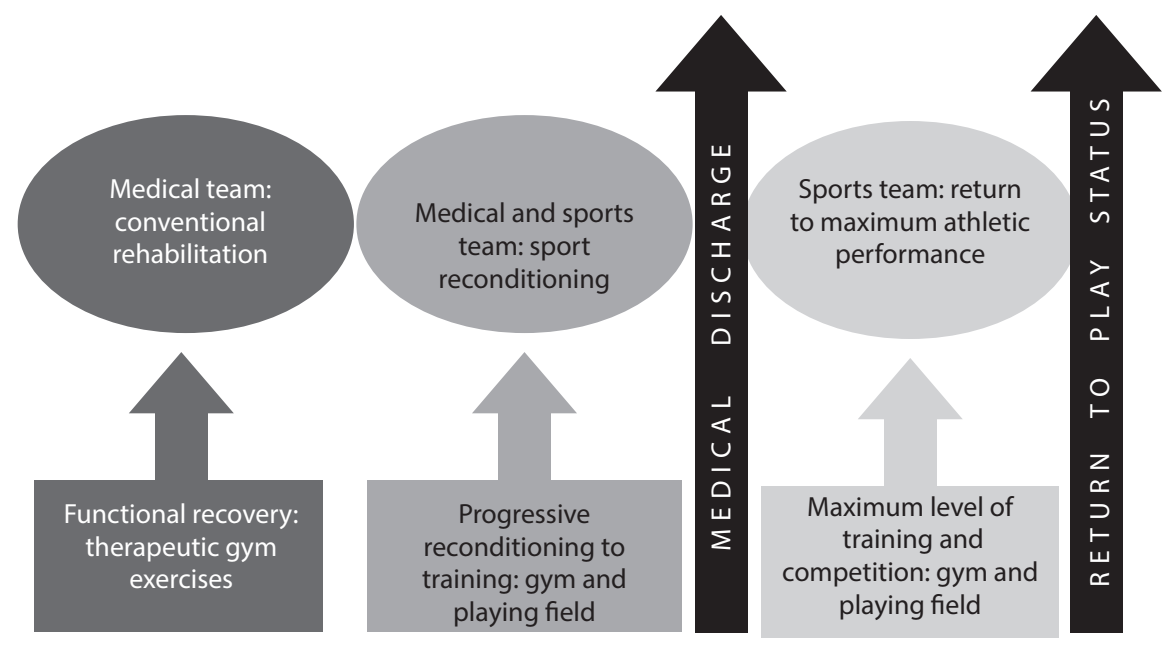

The approach to this initial phase aims to resolve the biological processes associated with the injury, including inflammatory and tissue repair mechanisms. This stage is therefore governed by biological and functional needs rather than specific times ${ }^{8}$. In this initial stage, the following goals must be ensured:

- Eliminate or reduce the pain, inflammation, effusion or oedema.

- Prevent greater damage ${ }^{9}$.

- Limit the damaging effects of disuse or prolonged rest ${ }^{9}$.

These goals can be met through the application of a number of strategies. Protection and rest following injury are directed at avoiding the mechanical overload of the tissue, which could aggravate the injury ${ }^{8,9}$. The prescription of non-steroidal anti-inflammatory drugs (NSAIDs) is common practice during this stage in order to control the pain and/or modulate the inflammatory process. However, their use is controversial in chronic phases of the injury or for prolonged use in muscular injuries $^{10}$. The use of various physical means ${ }^{11-15}$ is also a common treatment strategy in this phase. Likewise, intervention treatments through the infiltration of substances such as Platelet Rich Plasma, Hyaluronic Acid and Hypertonic Dextrose are becoming increasingly more common in the treatment of sports injuries ${ }^{16,17}$, reporting favourable effects in addressing muscle injuries ${ }^{18}$ and chronic tendinopathies ${ }^{19-21}$. In fact they represent an alternative to infiltration with corticosteroids which is still controversial for the treatment of some injuries due to the damaging effects that these can generate in tissue ${ }^{17,22}$.

Kinesiotherapy programs, based on early mobility and isometric strengthening, are a fundamental part of this stage ${ }^{23}$. The application of an optimal load to the affected site limits any undesirable effects of disuse and seeks a positive effect in the injured tissue reorganisation and healing 9,23 . Isometric strengthening ${ }^{24}$ and neuromuscular stimulation ${ }^{25,26}$ are effective therapeutic interventions to prevent arthrogenic muscle inhibition, muscular atrophy and to maintain the strength level following sports injuries ${ }^{24-26}$. It is feasible to perform such interventions right from the early stages of the injury.

On the other hand, from this stage onwards an optimal modified or adapted training load should be established, one which addresses the uninjured body parts and is able to prevent physical deconditioning without creating greater damage to the injured tissue. With this aim in mind, strategies can be used such as hydrotherapy to promote activities that unload the body weight ${ }^{27}$, strengthen the muscles not involved in the injured part of the body ${ }^{9}$ and allow for cross training, which is defined as the use of an activity or motor movement that involves less load for the injured part while maintaining physical performance ${ }^{28,29}$.

Some functional-clinical evolution criteria that the athlete must meet in order to progress to the following stage, could be the following:

- Adequate level in the process involving the repair, remodelling and stage of maturation of the damaged tissue, with no injury data in imaging studies ${ }^{30-32}$

- Asymptomatic physical examination: localized palpation with no pain or very slight pain ( $<3$ on the Visual Analogue Scale), full range of motion and with no pain, negative clinical tests and good joint stability ${ }^{30,31}$.

- Symmetrical pain-free muscle strength. It has been recommended that, at the end of this stage, the difference in strength between the injured and uninjured limbs must be less than 20\%30,33, which can be determined with hand-held isometric dynamometers that have been validated for the assessment of the muscles of the lower limbs, being a simple low-risk assessment that makes it possible to objectively determine the level of strength ${ }^{34}$. A further proposal is 
to achieve a minimum level of strength that permits the correct and asymptomatic movement of a load equivalent to 50\% of the body weight in the single-leg press exercise ${ }^{33}$.

- Walking with normal, asymptomatic patterns; abnormal walking patterns have been associated with muscle weakness, reduced functional performance and may be exacerbated when the patient starts to run. It is therefore essential to safely re-establish normal walking at an early stage prior to the start of the reconditioning process $^{33}$. It has been suggested that the injured athlete should be able to walk quickly for 10 minutes with a normal, pain-free mechanical pattern before commencing the Return to Performance stage ${ }^{30}$.

- Correct, asymptomatic performance of the bilateral squat, given that this exercise represents a basic motor pattern for the development of other motor tasks and it is highly recommendable to restore this motor pattern right from the early stages ${ }^{33}$. Some tests, such as the overhead squat, have been validated and are useful to identify abnormal patterns of motion that predispose to an injury / re-injury ${ }^{35}$.

\section{Return to Sport / Sports Reconditioning stage}

The Return to Sport or Sports Reconditioning stage represents a transition period between Return to Participation and Return to Performance. This stage is not performed in the physical therapy booths and/or in the therapeutic gym where conventional rehabilitation is normally done. Instead, it must be performed in the "physical fitness gymnasium" and on the "playing field" ${ }^{\text {. }}$. It must include the processes for reconditioning to training and competition. Therefore, "fieldwork" is an essential part given that, here, the athlete starts with a combination of activities (rehabilitation and modified training) focussing on progressing towards the asymptomatic performance of the activities forming part of the athlete's daily training and specific sports activity ${ }^{6,30}$. The sessions on the "playing field" are alternated with sessions in the "physical conditioning gym" to train strength, stability, flexibility and endurance, specifically adapted to the shortcomings of the athlete and to the type of injury ${ }^{30}$. It is important to emphasise the fact that, during this stage, the participation and supervision of the doctor coordinating the rehabilitation process is necessary. On successful completion of this stage, this doctor will then give the medical discharge ${ }^{6}$.

The Sports Reconditioning stage includes the rehabilitation of the shortcomings that are a product of the injury, as well as the maintenance and/or development of motor skills through modified physical training that primarily involves the uninjured body parts ${ }^{9,30}$. The levels of intervention and progress must be guided by the clinical-functional evolution until the athlete's injury is completely asymptomatic and there are no training restrictions ${ }^{30}$. The potential components of this stage are shown in Figure 3.

\section{Muscle strength reconditioning}

Muscle strength represents one of the main motor skills to be developed and standardised with regard to returning to sport following
Figure 3. Components of the Sports Reconditioning stage.

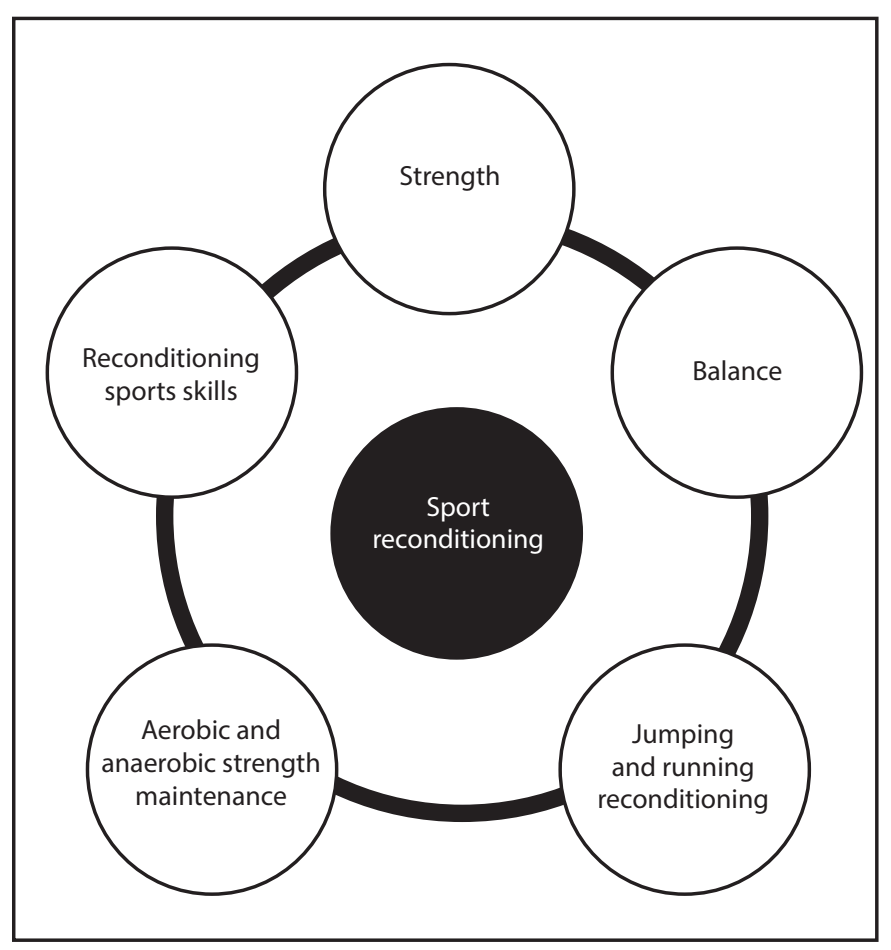

injury $^{30,36}$. It has been reported that muscle fatigue, the alteration of muscle activation over time, muscle imbalances between dominant and non-dominant limbs, alterations in muscle stiffness and lumbar abdominal strength defects are neuromuscular factors that could predispose to injury ${ }^{37}$. During the reconditioning stage, the degree of strength of the muscles related to the injured structure must be objectively assessed. To do so, the hand-held isometric dynamometer can be used ${ }^{34,38}$, or isokinetics, either in an open kinetic chain ${ }^{39,40}$ or in a closed kinetic chain ${ }^{41}$ or even in exercises with free weights such as the single leg press, leg extension or single leg flexion ${ }^{33,42}$. These tests make it possible to analyse the level of strength in relation to a pre-established reference value ${ }^{42}$, to compare the muscles of the injured limb with those of the uninjured one $e^{42,43}$ or to evaluate the agonist-antagonist ratio ${ }^{44}$. It has been suggested that, for isokinetic evaluations, at the end of the Reconditioning stage, athletes must have a difference of less than $10-15 \%$ when comparing the muscle strength of the injured limb with that of the uninjured one ${ }^{43}$. When isokinetic evaluation is not possible, consideration could be given to the single-leg press test as a functional test to assess the muscle strength levels in the injured limb $b^{33}$. In the comparison between agonist and antagonist muscles, the strength relationship varies according to the muscle group involved and the contraction regime in which the assessment is being made. For example, for open-chain isokinetic evaluations, it has been suggested that the ratio between the hamstrings (concentric): quadriceps (concentric) and the ratio between hamstrings (eccentric): quadriceps (concentric) must be greater than 0.6 and 1.0 respectively ${ }^{44}$. 
During the reconditioning stage, the dynamic strength program progresses from a partial joint range to a total joint range, according to the mechanical stress phase and level to which the injured structure is subject during the joint motion ${ }^{23}$. Although during sports training there is a proposal for the use of maximum repetition as a progression criterion for load intensity, during the reconditioning stage this criterion may not be applied in a similar fashion, given that the injured tissue is still in the repair-regeneration or remodelling process ${ }^{45}$. Therefore, the load intensity must be guided by the symptomatic response 30 and other variables such as the perception of effort ${ }^{45}$. It has been recommended that, during the reconditioning stage, the effects of the strengthening program should perhaps be focused on the improvement of resistance and muscle atrophy ${ }^{45}$. This can be achieved through the use of Roberston's OMNI RES scale that rates the perceived muscle effort at the end of the series and suggests using loads that make it possible to use series of 12 to 20 repetitions in order to improve muscle resistance and series of 8 to 12 repetitions in order to improve muscle strength and atrophy, with a perceived effort of more than 6 in order to guarantee muscle adaptations ${ }^{46}$. This strategy permits a balance between the safety and effectiveness of the program, in order to achieve greater benefits with no undesirable effects. When the injured structure is at advanced stages of remodelling or maturation, the strengthening loads could perhaps be guided by the conventional maximum repetition.

\section{Balance reconditioning}

Balance is defined as the ability to maintain the centre of gravity within the base of support with no loss of equilibrium ${ }^{47}$. The multiintervention neuromuscular training programs that included balance, lumbar abdominal strengthening, limb strengthening, jumps, etc. may reduce the risk of injuries and improve subsequent functionality for knee and ankle injuries ${ }^{48,49}$. It is important to start with the assessment of balance and dynamic posture control. A number of tests have been validated and used for this purpose, such as the Y Balance Test ${ }^{50}$, the Star Balance Test ${ }^{50}$ and the unilateral squat test ${ }^{51,52}$. The unilateral squat is a motor action that forms the basis of many sports movements and, in order to perform it, the athlete requires balance, neuromuscular control and the strength required to support and move all the body weight ${ }^{33}$. The asymptomatic and qualitatively correct performance of this test is required in order to progress in the reconditioning process ${ }^{33}$. Balance training can be started once the athlete is able to perform a pain-free unilateral squat with a complete load on the injured limb. It has been proposed to start with that the static balance training, progressing from two-leg to single-leg support, from work with visual information to the suppression of visual information, from stable surfaces to sloping or unstable surfaces, seeking to get close to postures that are similar to the sports gesture and/or that retain the injury mechanisms ${ }^{53,54}$. Subsequently, the athlete must progress to activities that challenge dynamic balance, starting with low-speed - low-load activities and progressing to high-speed - high-load activities ${ }^{53,54}$.

\section{Jump reconditioning and the plyometric movement}

Given that jumping is a high-speed, high-impact mechanical gesture that is an essential component of high-intensity sport activities such as running, braking, changing direction, reconditioning must take place before starting high-intensity training and competitive activity ${ }^{33,55}$ Jumping can be divided into 2 phases: an "impulse" phase where the muscles act concentrically, generating the necessary force for take-off and a "landing" phase where the muscles act eccentrically, generating the necessary shock-absorbing force. The combination of these phases through a short period of time, make up the plyometric movement ${ }^{56}$. The evaluation of this gesture is fundamental in the reconditioning stage and, for this purpose, use has been made of a number of tests such as the "Hop Jump test" test" validated and used in the prevention of injuries and the return to sport.

To start the two-leg jump reconditioning process, the following criteria have been proposed: absence of pain, inflammation and oedema ${ }^{56}$, complete, pain-free ranges of motion ${ }^{56}$, symmetrical pain-free muscle strength with a contralateral difference of less than $20 \%{ }^{33,56}$, qualitatively correct and asymptomatic performance of the unilateral squat ${ }^{33,56}$ and ability to asymptomatically perform a repetition of a single leg press with a load equivalent to $100 \%$ of the body weight ${ }^{33}$. Additionally, in the case of the reconditioning of the single leg jump, it has been suggested that the athlete should first be able to asymptomatically perform a repetition of a single leg press with a load equivalent to $150 \%$ of the body weight ${ }^{33}$

It has been suggested that the progression in the reconditioning process should start with low-intensity exercises such as "box jump ups" with emphasis on the impulse phase while minimising the landing phase, to subsequently progress to exercises of greater intensity such as "box drops" with emphasis on the landing phase ${ }^{33}$; Van Lieshout et al. ${ }^{60}$ determined that exercises such as "box jump ups" and "box drops" generate less joint load on the hip, knee and ankle than other types of exercises such as the countermovement jump, vertical jumps with knee flexion and drop jump. Following reconditioning of the impulse and landing phases, it has been suggested to start the reconditioning of the plyometric movement with exercises such as the "box to box jump" ${ }^{\prime \prime 3}$. This process must initially be performed for two-leg jumps and subsequently single-leg jumps ${ }^{33}$ and to progress from single jumps to consecutive jumps ${ }^{55,56}$. It has been proposed that, at the end of the reconditioning stage, the athlete must be able to achieve a performance greater than $90 \%$ with the injured limb (compared to the uninjured one) in functional jump tests such as the single-leg horizontal or vertical jump and/or consecutive jump tests such as the triple jump where the movement must also be asymptomatic and qualitatively correct ${ }^{57,61}$.

\section{Reconditioning of the running motor skill}

Running is the most frequently used movement in sport and, in biomechanical terms, it is considered to be a series of jumps ${ }^{62}$. The re- 
conditioning of running is a fundamental step in order to continue with the rest of the reconditioning process ${ }^{33}$ and, in general, it takes place on the "playing field" 6 although, in the initial stages, it could equally be performed on a treadmil| ${ }^{33}$. A few criteria suggested for the start of the low-intensity running reconditioning process are: absence of pain, inflammation and oedema ${ }^{63}$, full and pain-free ranges of motion ${ }^{63}$, quadriceps muscle strength with a contralateral difference of less than $20 \%{ }^{63}$, performance of a qualitatively correct and asymptomatic unilateral squat ${ }^{30,33,63}$ and ability to asymptomatically perform a single-leg press repetition with a load equivalent to $125 \%$ of the body weight ${ }^{33}$. It has been recommended to start the running reconditioning at speeds of around $8 \mathrm{~km} / \mathrm{h}^{33}$ and progress by increasing the running volume up to 20 minutes with no exacerbation of symptoms ${ }^{43}$. From then onwards, the running speed can be progressively increased, ensuring that this increase is in keeping with the clinical response $\mathrm{e}^{30}$.

The reconditioning of sprinting $(>25 \mathrm{~km} / \mathrm{h})^{42}$ will follow a different process. Given that sprinting is considered to be a series of jumps ${ }^{62}$, it is necessary to have completed the reconditioning of the single-leg plyometric movement before starting the reconditioning of sprinting (performance greater than 85\% with the injured limb compared to the uninjured one in the single-leg horizontal jump ${ }^{63}$, as well as having achieved a contralateral difference of less than 10\% in the quadriceps muscle strength ${ }^{33}$ and ability to asymptomatically perform a single-leg press repetition with a load equivalent to $125 \%$ of the body weight ${ }^{33}$. The reconditioning process could perhaps start with the performance of running drills made with a high frequency of movement in 20-40 metre sections, simulating a sprint but with a shorter stride, involving less muscle stress and joint load ${ }^{64}$. Once this is achieved asymptomatically, sprinting can start, equally in short sections of around 20-240 metres, where the speed shall be progressively increased, guided by the patient's symptomatology $y^{30,43}$, until the maximum sprinting speed has been reached asymptomatically.

Once reconditioning has been achieved for the maximum linear sprinting speed, then, agility work can start. This is defined as the ability to decelerate, accelerate and make changes of direction at the greatest possible speed and with the least loss of intensity ${ }^{65}$ and represents one of the final components in the reconditioning process ${ }^{33}$. Given that agility exercises require high levels of strength, neuromuscular control and reactive ability, a few criteria have been suggested for the start of the agility reconditioning process: quadriceps muscle strength with a contralateral difference of less than $10 \%{ }^{33}$, ability to asymptomatically perform a single-leg press repetition with a load equivalent to $200 \%$ of the body weight ${ }^{33}$ and the successful reconditioning of the plyometric movement. Exercises can be included such as the "agility ladder","carioca drills", running backwards and sideways, accelerations-decelerations, turns, changes in direction, etc. ${ }^{43,66}$, with a gradual increase in speed and symptomatic control. Progress can be assessed with agility tests that include movements similar to those used in the sport in question, such as the "Edgren Side Step Test", "T-Test" and "Illinois Agility Test"65.
These tests often represent a criterion to start sport-specific training and competition activities ${ }^{33,67}$.

\section{Maintenance of the physical condition}

EMaintenance of the physical condition must be a priority component of the sports rehabilitation and reconditioning processes. Maintenance of aerobic strength must be made at all stages of the process. Cross training has been used for this ${ }^{28,29}$. For injuries to a lower limb, activities such as deep water running ${ }^{\prime 27}$ and/or an arm ergometer ${ }^{68}$ can be used from very early stages when the injured structure requires complete unloading. In keeping with the type of injury or when the complete unloading of the injured structure is not necessary, other activities such as the ergometric or elliptical bike are also effective in maintaining and even improving an injured athlete's aerobic capacity ${ }^{28,29}$. On the other hand, the uninjured structures must be trained as normal in order to maintain or even improve the muscular strength levels, independently of the therapeutic work to strengthen the injured structure9,45. It may also be possible to train anaerobic strength through cross training, for which the same ergometers can be used, provided that the injured body structure, the type of injury and the stage of recovery from the injury permit this.

\section{Reconditioning athletic skills}

The reconditioning of the sport-specific motor skills and their technical aspects must be introduced from the start of the reconditioning stage. This should be started at low-speed, emphasising correct execution, given that this will promote the acquisition and consolidation of the correct movement patterns, preparing the athlete for the subsequent phases in which the movements will be made at greater speed, including complex, multi-directional and reactive movements, including sports implements, challenges related to the sport context and the participation of adversaries ${ }^{30,33}$.

\section{Duration and criteria of the reconditioning stage}

The duration of this stage will depend on the type of injury and its specific context.

The progress and safety of the programme must be based on clinical data and must be closely monitored throughout its duration, considering data on the overloading of the tissue under repair, the appearance of pain, oedema or inflammation ${ }^{30}$. The following criteria should be taken into account in order to conclude this stage and start the Return to Performance stage:

- Injured tissue healing process successfully completed, with no signs and symptoms when performing the activities characteristic of this stage.

- Symmetrical muscle strength of the lower limb, with a contralateral difference of less than 10\% when comparing the injured limb to the uninjured one $e^{33,61}$ and restored agonist-antagonist muscle 
balance ${ }^{43}$. Ability to asymptomatically perform a repetition of a single leg press with a load equivalent to $200 \%$ of the body weight ${ }^{33}$.

- Qualitatively correct plyometric movement and with a performance in functional jump tests of $90 \%$ when comparing the injured limb to the uninjured one ${ }^{57,61}$

- Ability to asymptomatically perform a linear, multi-directional sprint ${ }^{30}$ and good quality, asymptomatic agility tes ${ }^{\mathrm{t} 33,67}$.

- Correct, asymptomatic technical execution of the sports movement $^{30,33}$.

\section{Return to Performance stage}

This should be started once the Return to Participation and Return to Sport (reconditioning) stages have been completed successfully. At this point in the process, the athlete has recovered from the injury and has been given the "medical discharge" but has not yet reached the levels of physical, technical and tactical preparation to reach the maximum performance leve $\left.\right|^{4,6}$ and to guarantee an adequate return with less risk of re-injury $y^{6}$. The athlete has therefore not yet been given the go ahead to "return to play".

The goals for this stage are:

- Achieve the levels of physical, technical and tactical preparation that allow the athlete to achieve the maximum performance level${ }^{1,6}$.

- Reduce the risk of re-injury, which will be increased per se $e^{4,31}$.

For this purpose, the sports training programmes will be the main component of this stage. These programmes must be prepared and supervised by the sports team (trainer/fitness coach) which will act on the playing field and in the physical conditioning gym ${ }^{6,7}$. However, the medical team must continue to be involved, with the focus on reducing the risk of re-injury, as well as actively taking part in the medical control of the sport training ${ }^{69}$.

During this stage, the athlete plays an unrestricted part in all the activities involved in their normal sports training, in line with the methodology put forward by the trainer ${ }^{6,7}$. Furthermore, the athlete can take part in pre-competition activities, low-demand or short-duration competitive matches, progressing to achieve or exceed the pre-injury performance level. At this point, the athlete shall be given the "return to play" status, considering the RTP process to have successfully concluded".

\section{Conclusions}

Return to Sport must be a continuum, addressed by a multidisciplinary team involving a range of professionals having the training and expertise in dealing with sports injuries. It must contemplate all factors (biological-structural, functional, sports, personal, psychosocial and environmental) that may influence the Return to Sport. A 3-stage model that includes Return to Participation, Return to Sport, and Return to Performance, could be a feasible proposal that could be associated with greater success in the return to sporting activity, less risk of re-injury and a greater possibility of achieving the pre-injury performance level.

\section{Conflict of interest}

The authors have no conflict of interest at all.

\section{Bibliography}

1. Hodgson L, Gissane C, Gabbett TJ, King DA. For Debate: Consensus injury definitions in team sports should focus on encompassing all Injuries. Clin J Sport Med. 2007;17:188-91.

2. Timpka T, Jacobsson J, Bickenbach J, Finch CF, Ekberg J, Nordenfelt L. What is a sports injury? Sports Med. 2014;44:423-8.

3. Dijkstra HP, Pollock N, Chakraverty R, Ardern CL. Return to play in elite sport: a shared decision-making process. Br J Sports Med. 2017:51:419-20.

4. Ardern CL, Glasgow P, Schneiders A, Witvrouw E, Clarsen B, Cools A, et al. 2016 Consensus statement on return to sport from the first world congress in sports physica therapy, Bern. Br J Sports Med. 2016;50:853-64.

5. Ardern $C L$, Bizzini $M, B a h r ~ R$. It is time for consensus on return to play after injury: five key questions. Br J Sports Med. 2015;50:506-8.

6. Buckthorpe M, Frizziero A, Roi GS. Update on functional recovery process for the injured athlete: return to sport continuum redefined. Br J Sports Med. 2019;53:265-7.

7. Rojas-Valverde D, Gutiérrez-Vargas JC, Sánchez-Ureña B. Sport Readaptation: Where do we draw the lines between professionals?. Front. Sports Act. Living. 2019;1:1-5.

8. Bleakley CM, Glasgow P, MacAuley DC. PRICE needs updating, should we call the POLICE? Br J Sports Med. 2012;46:220-1.

9. Dhillon H, Dhilllon S, Dhillon MS. Current concepts in sports injury rehabilitation. Indian J Orthop. 2017;51:529-36.

10. Paoloni J A, Milne C, Orchard J, Hamilton B. Non-steroidal anti-inflammatory drugs in sports medicine: guidelines for practical but sensible use. Br JSports Med. 2009;43:863-5.

11. Yu H, Randhawa K, Côté P, Optima Collaboration. The effectiveness of physical agents for lower-limb soft tissue injuries: a systematic review. J Orthop Sports Phys Ther 2016:46:523-54

12. Malanga GA, Yan N, Stark J. Mechanisms and efficacy of heat and cold therapies for musculoskeletal injury. Postgrad Med. 2015;127:57-65.

13. Clijsen R, Brunner A, Barbero M, Clarys P,Taeymans J. Effects of low-level laser therapy on pain in patients with musculoskeletal disorders: a systematic review and metaanalysis. Eur J Phys Rehabil Med. 2017;53:603-10

14. Liao CD, Xie GM, Tsauo JY, Chen HC, Liou TH. Efficacy of extracorporeal shock wave therapy for knee tendinopathies and other soft tissue disorders: a meta-analysis of randomized controlled trials. BMC Musculoskelet Disord. 2018;19:278.

15. Lou S, LV H, Li Z, Zhang L, Tang P. The effects of low-intensity pulsed ultrasound on fresh fracture: A meta-analysis. Medicine (Baltimore). 2017;96:e8181.

16. Olafsen NP, Herring SA. Pain management in sport: therapeutic injections. Handb Clin Neurol. 2018;158:431-42.

17. del Valle - Soto M, Jiménez-Díaz F, Manonelles-Marqueta P, Ramírez-Parenteau C, Rodríguez-Vicente JM, Serratosa-Fernández L. Consenso sobre utilización de las infiltraciones en el deporte. documento de consenso de la sociedad española de medicina del deporte. Arch Med Deporte. 2016;33:114-25.

18. Sheth U, Dwyer T, Smith I, Wasserstein D, Theodoropoulos J, Takhar S, et al. Does platelet-rich plasma lead to earlier return to sport when compared with conservative treatment in acute muscle injuries? a systematic review and meta-analysis. Arthroscopy. 2018;34:281-8

19. Chen $X$, Jones IA, Park C, Vangsness CT Jr. The efficacy of platelet-rich plasma on tendon and ligament healing: a systematic review and meta-analysis with bias assessment. Am J Sports Med. 2018;46:2020-32.

20. Neph A, Onishi K, Wang J. Myths and facts of in-office regenerative procedures for tendinopathy. Am J Phys Med Rehabil. 2019;98: 500-11.

21. Sanderson LM. Bryant A. Effectiveness and safety of prolotherapy injections for management of lower limb tendinopathy and fasciopathy: a systematic review. J Foot Ankle Res. 2015;8:57.

22. Olafsen NP, Herring SA, Orchard JW. Injectable corticosteroids in sport. Clin J Sport Med. 2018:28:451-6.

23. Caparrós T, Pujol M, Salas C. General guidelines in the rehabilitation process for return to training after a sports injury. Apunts Med Esport. 2017;52:167-72.

24. Oranchuk DJ, Storey AG, Nelson AR, Cronin JB. isometric training and long-term adaptations: effects of muscle length, intensity, and intent: a systematic review. Scand J Med Sci Sports. 2019;29:484-503. 
25. Maffiuletti NA, Gondin J, Place N, Stevens-Lapsley J, Vivodtzev I, Minetto MA. Clinical use of neuromuscular electrical stimulation for neuromuscular rehabilitation: what are we overlooking? Arch Phys Med Rehabil. 2018;99:806-12.

26. Hauger AV, Reiman MP, Bjordal JM, Sheets C, Ledbetter L, Goode AP. Neuromuscular electrical stimulation is effective in strengthening the quadriceps muscle after anterior cruciate ligament surgery. Knee Surg Sports Traumatol Arthrosc. 2018;26:399-410.

27. Buckthorpe M, Pirotti E, Villa FD. Benefits and use of aquatic therapy during rehabilitation after ACL reconstruction -a clinical commentary. Int J Sports Phys Ther. 2019;14:978-93.

28. Paquette MR, Peel SA, Smith RE, Temme M, Dwyer JN. The impact of different crosstraining modalities on performance and injury-related variables in high school cross country runners. J Strength Cond Res. 2018;32:1745-53.

29. Baker BD, Lapierre SS, Tanaka H. Role of cross-training in orthopaedic injuries and healthcare burden in masters swimmers. Int J Sports Med. 2019:40:52-6.

30. Roi GS. Return to competition following athletic injury: Sports rehabilitation as a whole. Apunts Med Esport. 2010;45:181-4.

31. Creighton DW, Shrier I, Shultz R, Meeuwisse WH, Matheson GO. Return-to-play in sport: a decision-based model. Clin J Sport Med. 2010;20:379-85.

32. Bisciotti GN, Volpi P, Alberti G, Aprato A, Artina M, Auci A. Italian consensus statement (2020) on return to play after lower limb muscle injury in football (soccer). BMJ Open Sport Exerc Med. 2019;5:e000505.

33. Buckthorpe $M$, Tamisari A, Villa FD. A ten task-based progression in rehabilitation after $A C L$ reconstruction: from post-surgery to return to play - a clinical commentary. Int J Sports Phys Ther. 2020;15:611-23.

34. Mentiplay BF, Perraton LG, Bower KJ, Adair B, Pua YH, Williams GP, et al. Assessment of lower limb muscle strength and power using hand-held and fixed dynamometry: a reliability and validity study. PLOS One. 2015;10:e0140822.

35. Post EG, Olson M, Trigsted S, Hetzel S, Bell DR. The reliability and discriminative ability of the overhead squat test for observational screening of medial knee displacement. J Sport Rehabil. 2017;26. doi: 10.1123/jsr.2015-0178.

36. Czuppon S, Racette BA, Klein SE, Harris-Hayes M. Variables associated with return to sport following anterior cruciate ligament reconstruction: a systematic review. $\mathrm{Br} J$ Sports Med. 2014;48:356-64.

37. Fort-Vanmeerhaeghea A, Romero-Rodríguez D. Análisis de los factores de riesgo neuromusculares de las lesiones deportivas. Apunts Med Esport. 2013;48:109-20.

38. Almeida GPL. Albano TR, Melo AKP. Hand-held dynamometer identifies asymmetries in torque of the quadriceps muscle after anterior cruciate ligament reconstruction. Knee Surg Sports Traumatol Arthrosc. 2019;27:2494-501.

39. Cvjetkovic DD, Bijeljac S, Palija S, Talic G, Radulovic TN, Kosanovic MG, et al. Isokinetic testing in evaluation rehabilitation outcome after $\mathrm{ACL}$ reconstruction. Med Arch. 2015;69:21-3

40. Liporaci RF, Saad M, Grossi DB, Riberto M. Clinical features and isokinetic parameters in assessing injury risk in elite football players. Int J Sports Med. 2019;40:903-8.

41. Dvir Z, Müller S. Multiple-joint isokinetic dynamometry: a critical review. J Strength Cond Res. 2020;34:587-601.

42. Clark NC, Reilly LJ, Davies SC. Intra-rater reliability, measurement precision, and inter-test correlations of 1 RM single-leg leg-press, knee-flexion, and knee-extension in uninjured adult agility-sport athletes: Considerations for right and left unilateral measurements in knee injury control. Phys Ther Sport. 2019;40:128-36.

43. Sclafani MP, Davis CC. Return to play progression for rugby following injury to the lower extremity: a clinical commentary and review of the literature. Int I Sports Phys Ther. 2016;11:302-20.

44. Dauty M, Menu P, Fouasson-Chailloux A. Cut-offs of isokinetic strength ratio and hamstring strain prediction in professional soccer players. Scand J Med Sci Sports. 2018;28:276-81.

45. Reiman MP, Lorenz DS. Integration of strength and conditioning principles into a rehabilitation program. Int J Sports Phys Ther. 2011;6:241-53.

46. Helms ER, Cronin J, Storey A, Zourdos MC. Application of the repetitions in reservebased rating of perceived exertion scale for resistance training. Strength Cond J. 2016;38:42-9.

47. Hrysomallis C. Balance ability and athletic performance. Sports Med. 2011;41:221-32.

48. Dargo L, Robinson KJ, Games KE. prevention of knee and anterior cruciate ligament injuries through the use of neuromuscular and proprioceptive training: an evidencebased review. J Ath/ Train. 2017:52:1171-2.
49. De Vasconcelos GS, Cini A, Sbruzzi G, Lima CS. Effects of proprioceptive training on the incidence of ankle sprain in athletes: systematic review and meta-analysis. Clin Rehabil. 2018;32:1581-90.

50. Chimera NJ, Warren M. Use of clinical movement screening tests to predict injury in sport. World J Orthop. 2016;7:202-17.

51. Hall MP, Paik RS, Ware AJ, Mohr KJ, Limpisvasti O. Neuromuscular evaluation with single-leg squat test at 6 months after anterior cruciate ligament reconstruction. Orthop J Sports Med. 2015;3:2325967115575900

52. Ressman J, Grooten WJA, Rasmussen Barr E. Visual assessment of movement quality in the single leg squat test: a review and meta-analysis of inter-rater and intra-rater reliability. BMJ Open Sport Exerc Med. 2019;5:e000541.

53. Muehlbauer T, Roth R, Bopp M, Granacher U. An exercise sequence for progression in balance training. J Strength Cond Res. 2012;26:568-74.

54. Lesinski M, Hortobágyi T, Muehlbauer T, Gollhofer A, Granacher U. Dose-response relationships of balance training in healthy young adults: a systematic review and meta-analysis. Sports Med. 2015;45:557-76.

55. Chmielewski TL, Myer GD, Kauffman D, Tillman SM. Plyometric exercise in the rehabilitation of athletes: physiological responses and clinical application. J Orthop Sports Phys Ther. 2006:36:308-19.

56. Davies G, Riemann BL, Manske R. Current concepts of plyometric exercise. Int J Sports Phys Ther. 2015;10:760-86.

57. Peebles AT, Renner KE, Miller TK, Moskal JT, Queen RM. Associations between Distance and Loading Symmetry during Return to Sport Hop Testing. Med Sci Sports Exerc. 2019;51:624-9

58. Lee DW, Yang SJ, Cho SI, Lee JH, Kim JG. Single-leg vertical jump test as a functional test after anterior cruciate ligament reconstruction. Knee. 2018;25:1016-26.

59. Fransz DP, Huurnink A, Kingma I, de BoodeVA, Heyligers IC, Van Dieën JH. Performance on a single-legged drop-jump landing test is related to increased risk of lateral ankle sprains among male elite soccer players: a 3-year prospective cohort study. Am J Sports Med. 2018;46:3454-62.

60. Van Lieshout KG, Anderson JG, Shelburne KB, Davidson BS. Intensity rankings of plyometric exercises using joint power absorption. Clin Biomech. 2014;29:918-22.

61. Thomeé R, Kaplan Y, Kvist J, Myklebust G, Risberg MA, Theisen D. Muscle strength and hop performance criteria prior to return to sports after $A C L$ reconstruction. Knee Surg Sports Traumatol Arthrosc. 2011;19:1798-805.

62. Nicola TL, Jewison DJ. The anatomy and biomechanics of running. Clin Sports Med. 2012;31:187-201.

63. Rambaud AJM, Ardern CL, Thoreux P, Regnaux JP, Edouard P. Criteria for return to running after anterior cruciate ligament reconstruction: a scoping review. Br J Sports Med. 2018;52:1437- 44

64. Askling CM, Tengvar M, Tarassova O, Thorstensson A. Acute hamstring injuries in Swedish elite sprinters and jumpers: a prospective randomised controlled clinical trial comparing two rehabilitation protocols. Br J Sports Med. 2014;48:532-9.

65. Raya MA, Gailey RS, Gaunaurd IA, Jayne DM, Campbell SM, Gagne E, et al. Comparison of three agility tests with male servicemembers: edgren side step test, t-test, and illinois agility test. J Rehabil Res Dev. 2013;50:951-60.

66. Holmberg PM: Agility Training for Experienced Athletes: A Dynamical Systems Approach. Strength and Conditioning Journal. 2015;37:93-8.

67. Clover J, Wall J. Return-to-play criteria following sports injury. Clin Sports Med. 2010;29:169-75.

68. Hettinga FJ, Hoogwerf M, Van der Woude LHV. Handcycling: training effects of a specific dose of upper body endurance training in females. Eur J Appl Physiol. 2016;116:1387-94.

69. Dijkstra HP, Pollock N, Chakraverty R, Alonso JM. Managing the health of the elite athlete: a new integrated performance health management and coaching model. $\mathrm{Br}$ J Sports Med. 2014;48:523-31. 